\title{
KOMODIFIKASI HIJAB DALAM IKLAN KOSMETIK SOPHIE PARIS VERSI “NATURAL \& HALAL” DI TELEVISI
}

\author{
Oleh: Hana Qodzari Mayaningrum ${ }^{1}$ dan Agus Triyono ${ }^{2}$ \\ Prodi Ilmu Komunikasi \\ Universitas Muhammadiyah Surakarta \\ E-mail: hqodzari@ymail.com1, agus.triyono@ums.ac.id2
}

\begin{abstract}
Abstrak
Iklan merupakan salah satu produk media massa yang digunakan sebagai media pemasaran. Ketika iklan menggunakan Perempuan berhijab sebagai model iklannya, maka akan mengubah pandangan masyarakat terhadap Perempuan berhijab. Dalam hal ini, pandangan yang ditonjolkan adalah iklan yang menggunakan Perempuan berhijab. Iklan yang dianalisis dalam penelitian ini adalah iklan kosmetik Sophie Paris "Natural \& Halal" 2014 dan Karina Nadila sebagai brand ambassadornya. Tujuan dari penelitian ini untuk menegaskan bahwa memang terdapat komodifikasi yang bertujuan untuk menarik minat konsumen dalam meningkatkan penjualan. Penelitian ini termasuk jenis penelitian analisis isi dengan pendekatan kualitatif. Analisis yang digunakan adalah Semiotika menurut Charles Sanders Pierce. Data utama yang digunakan adalah video iklan kosmetik Sophie Paris "Natural \& Halal" dandata pendukung yang digunakan diperoleh dari dokumentasi yang berbentuk tulisan, gambar, atau karya-karya monumental dan beberapa buku atau jurnal yang terkait dengan penelitian komodifikasi, periklanan, hijab. Iklan kosmetik Sophie Paris "Natural \& Halal" menjadikan hijab sebagai sebuah nilai jual (komoditas) dan kepentingan tertentu untuk mendapatkan sebuah keuntungan. Setelah dilakukan analisis, hasil penelitian ini menunjukkan bahwa komodifikasi yang muncul pada iklan kosmetik Sophie Paris "Natural \& Halal" adalah komodifikasi konten yang terlihat dari tanda-tanda dan makna dari penggambaran cerita tersebut. Penggunaan hijab yang dikomodifikasikan menyebabkan iklan mengalami pergeseran dari nilai fungsi ke nilai tukar. Di mana nilai fungsi hijab yang seharusnya dipergunakan untuk beribadah kepada Allah, namun dalam kenyataannya dijadikan sebagai pengeruk keuntungan yang berlimpah untuk sebuah perusahaan.
\end{abstract}

Kata Kunci: Komodifikasi, Hijab, Iklan Televisi.

\begin{abstract}
Advertising is one of the products that use the mass media as a marketing medium. When an ad using veiled women as a model of his ad, it will change society's view of women hijab. In this case, you'll enjoy the view of advertising that uses women hijab. Ads were analyzed in this study is a cosmetic advertisement Sophie Paris "Natural \& Halal" in 2014 and Karina Barbie as a brand ambassadornya. Sophie Paris itself is a product from abroad who want venturing into Indonesia. The purpose of this study to confirm that there was indeed a commodification that aims to attract customers in increasing sales. This research includes a content analysis study with a qualitative approach. The analysis is Semiotics by Charles Sanders Pierce. Key data used is cosmetics advertising video Sophie Paris "Natural \& Halal" and supporting data used were obtained from documentation in the form of text, images, or monumental works and several books or journals associated with the commodification research, advertising, hijab. Sophie Paris cosmetics advertising "Natural \& Halal" make the hijab as a sales value (commodities) and of particular interest to gain an advantage. After analysis, the results of this study indicate that the
\end{abstract}


commoditization of cosmetic advertisements appearing on Sophie Paris "Natural \& Halal" is the commodification of the visible content of the signs and the meaning of the depictions of the story. The use of hijab is commodified cause a shift of advertising to the exchange rate value of the function. Where the value of the function hijab should be used to worship God, but in fact serve as a scraper with enormous profits for a company.

Keywords: Commodification, Hijab, Television Ads.

\section{A. Pendahuluan}

Televisi memiliki peran paling besar dalam realitas sosial yang sedang berkembang seperti saat ini. Media televisi bukan sekedar menyebarkan informasi keseluruh benua, tetapi juga merupakan perantara untuk menyusun agenda dan memberitahukan hal-hal penting bagi manusia. Lambat-laun media televisi menjadi sarana untuk menukarkan nilai guna menjadi nilai tukar (Indriyani, 2016). Mosco mengungkapkan bahwa ekonomi politik telah dipengaruhi oleh ekonomi politik dari komunikasi yang erat kaitanyya dengan hubungan sosial antara manusia dalam proses produksi, distribusi, pertukaran dan konsumsi terhadap keuntungan material. Komodifikasi membuat peubahan nilai atau fungsi dari suatu barang maupun jasa menjadi komoditi atau barang yang bernilai ekonomi (Susanthi, 2013).

Salah satu program televisi yang memiliki dampak langsung ke masyarakat adalah iklan. Menurut Wright iklan merupakan suatu alat yang digunakan untuk mengarahkan komunikasi persuasif pada masyarakat. Iklan memiliki fungsi utama untuk menyampaikan informasi suatu produk kepada khalayak. Iklan dapat didengar dan dilihat dimana saja karena iklan merupakan bentuk promosi yang ada di berbagai tempat (Indriyani, 2016). Selain itu iklan juga dapat mempengaruhi para konsumen untuk membeli produk yang mereka iklankan (Guna, 2014). Salah satu iklan yang mencoba menarik konsumen, yaitu iklan kosmetik Sophie Paris Versi "Natural \& Halal” yang dalam iklan tersebut menggunakan perempuan berhijab untuk menarik konsumen.

Perbincangan tentang jilbab memang tidak pernah berhenti. Seolah mengalami metamorfosis, jilbab di Indonesia berkembang setahap demi setahap. Di Indonesia, jilbab seringkali disama artikan dengan hijab. Pengertian umum yang berlaku saat ini mengenai hijab adalah pakaian muslimah; kerudung (simpel headscarf); atau pakaian longgar yang tak tembus cahaya. Sedangkan ketika berbicara mengenai jilbab, seseorang biasanya mengacu kepada kerudung yang diikatkan pada kepala, dan biasanya dikenakan perempuan muslimah (Triantini, 2014).

Indonesia sendiri termasuk salah satu negara Muslim terbesar di dunia, namun demikian fenomena berjilbab (dan bercadar) baru mulai mendapatkan perhatian beberapa tahun terakhir. (Ratri, 2011). Pada masa Orde Lama perempuan yang menggunakan jilbab dianggap kolot, terbelakang, tidak modern dan lain sebagainya, lain halnya pada masa Orde Baru perempuan menggunakan jilbab justru malah dianggap berwibawa dan terhormat, bahkan pada masa ini pula tepatnya pada tahun 1991 pemerintah mengeluarkan kebijakan diperbolehkanya memakai jilbab di sekolah. Sekarang di masa Orde Reformasi perempuan memakai jilbab bukan hal yang langka lagi (Triantini, 2014) 
Diterbitkan oleh Program Studi IImu Komunikasi

Universitas Ahmad Dahlan Yogyakarta

Sebelum Order Reformasi sejarah jilbab di berbagai pelosok dunia telah menyimpan begitu banyak catatan tentang deskriminasi jilbab. Terlebih di Barat, jilbab seolah menjadi monster mengerikan yang harus dienyahkan dari kehidupan sosial, budaya ataupun politik. Sehingga tak heran, pembatasan dan pelarangan terhadap jilbab dituangkan dalam ranah peraturan perundang-undangan negara. Peraturan melarang pemakaian burqa secara nasional di seluruh wilayah Belanda ditetapkan pada Desember 2006. Mulai Juni 2006, larangan pemakaian jilbab meluas di Jerman. 8 dari 16 negara bagian di negeri menerapkan larangan pemakaian jilbab di sekolah-sekolah umum Jerman. Bahkan, larangan terhadap busana yang memuliakan kaum muslimah tidak hanya terjadi di negara-negara Barat saja. Republik Tunisia, sebuah negara Arab Muslim yang terletak di Afrika Utara, tepatnya di pesisir Laut Tengah memiliki sejarah panjang dalam mendiskreditkan jilbab (Ratri, 2011).

Perkembangan terkini, kelas menengah Indonesia yang makin banyak jumlahnya, sebagian yang cukup besar adalah umat Islam yang semakin sadar akan keislaman mereka. Banyaknya masyarakat yang ingin menggunakan jilbab membuat munculnya para perancang busana Muslimah Indonesia. Indonesia mungkin bisa menjadi salah satu pusat mode busana Muslimah di dunia. Mode dan desain jilbab di Indonesia memang terus berkembang secara dinamis dan menjadi bagian dari gaya hidup kaum muslimah di Indonesia (Triantini, 2014).

Gaya berhijab yang ditampilkan perempuan muslimah mulai disorot oleh media. Media sendiri merupakan tempat untuk menampilkan segala sesuatu yang bertujuan untuk diperlihatkan ke masyarakat luas (Morissan, 2010). Iklan saat ini mulai memasuki dunia baru yaitu dunia hijab. Fenomena dimana berkembangnya kemajuan gaya serta fashion yang saat ini sedang bermunculan. Iklan mulai menggunakan perempuan berhijab sebagai model utamanya, terlihat dari beberapa iklan kosmetik yang muncul di televisi. Bahkan bukan hanya iklan kosmetik saja, masih banyak iklan lainnya yang mulai menggunakan hijab misalnya iklan shampo, iklan kartu perdana pun ikut menggunakan Perempuan hijab sebagai model utamanya. Sehingga muncul sebuah fenomena baru tentang perekembangan hijab (Pertiwi, 2015).

Pengusaha mulai melihat celah ini dan mengambil kesempatan untuk mengiklankan produknya menggunakan Perempuan berhijab agar lebih cepat dikenal masyarakat. Iklan sendiri merupakan wujud dari komunikasi yang memasarkan sebuah produk, servis dan ide yang dikemas dengan sedemikian rupa, sehingga diterima khalayak luas. Dari ide yang dikeluarkan mendapatkan sebuah timbal balik berupa uang yang diberikan sesuai dengan persetujuan awal yang dibuat oleh perusahaan yang menginginkan produknya diiklankan dengan pemilik ide yang membuat iklan diterima di masyarakat (Morissan, 2010).

Penggunaan muslimah sebagai ikon atau bintang iklan membuat ketertarikan sendiri pada konsumen. Hal ini sesuai dari penelitian Indriyani, (2016) dimana penggunaan endorser Laudya Cynthia Bella mempengaruhi kalangan Perempuan berhijab. Sebagai contoh adalah mulai munculnya artis yang menggunakan hijab dalam beberapa produk kosmetik seperti Inneke Koesherawati, Sandra Dewi, Alisa Soebandono, Dian Pelangi, Shireen Sungkar dan Zee Zee Shahab. Selain itu, juga memberikan kesempatan iklan untuk meraup untung yang lebih banyak. Disini Perempuan terlihat 
dijadikan sebagai komoditas suatu iklan dalam produk tertentu. Komodifkasi itu membuat perubahan sebuah ide, karya, nilai, barang dan sebagainya menjadi sebuah kebiasaan untuk meningkatkan keuntungan yang lebih banyak. Seperti penelitian Shirazi, (2010) yang melakukan komodifikasi terhadap boneka berhijab yang ada di negara Timur Tengah dan Saudi Arabia, dijelaskan bahwa boneka adalah mainan atau benda yang biasa digunakan untuk bermain. Kemudian muncul adanya komodifikasi dalam tampilan boneka. Boneka yang sebelumnya tidak berhijab sekarang dimodifikasi dengan menggunakan hijab. Ada kaitan antara hijab dan komodifikasi. Penulis berupaya untuk mengkaitkan antara hijab dengan perempuan. Sehingga terdapat perbedaan objek yang menjadi dasar penelitian.

Selain itu menurut Hassim (2014) perempuan saat ini menjadi konsumen dan sebagai sumber kekuatan informasi yang pada akhirnya akan mempengaruhi komunitas lainnya. Adanya perbedaan antara kesederhanaan fashion Perempuan Muslim melayu dan pengaruh Perempuan Muslim dalam struktur politik mendasari pembuatan jurnal ini. Lebih lanjut ia menjelaskan bahwa hijab sekarang ini berubah fungsinya menjadi sebuah simbol keduniawian. Hijab sering digunakan para artis saat tampil setiap harinya. Mereka cenderung menggunakan berbagai macam hijab yang penuh gaya. Sama halnya dengan penelitian yang dilakukan oleh peneliti, di mana hijab digunakan sebagai salah satu objek yang berhubungan erat dengan Perempuan serta komodifikasinya dalam dunia kosmetik. Lebih lanjut, Robinson (2015) menjelaskan bagaimana suatu negara menganggap adanya peran terselubung dalam mengatur perempuan dalam lingkup politik dan dalam bentuk komoditas.

Ada pula penelitian yang dilakukan oleh Jenaibi, (2008) yang pada intinya mengkaji tentang versi tradisional identitas Perempuan Arab menjadi sebuah materi dalam persaingan iklan komersial. Iklan komersial dari sebuah produk cenderung menonjolkan Perempuan Muslim modern yang berhijab. Komodifikasi Perempuan dan hijab nampak nyata dalam penelitian tersebut.

Media iklan terkesan sangat memanfaatkan situasiberkembangnyahijab untuk menarik minat konsumen agar membeli produk-produk mereka.Dalam hal ini Perempuan berhijab diharapkan dapat mendongkrak penjualan produk-produkter tentu. Seperti produk kosmetik yang diusung oleh Sophie Paris dengan tema "Natural \& Halal" dimana dalam iklan tersebut menggunakan model Perempuan berhijab yang diperankan oleh Karina Nadila. Kelebihan iklan ini penuh dengan tanda-tanda yang mengidentifikasi adanya komodifikasi hijab dalam memasarkan produknya. Iklan di televisi biasanya menggunakan sosok perempuan yang cantik, berambut panjang yang diurai, berkulit putih, dan memiliki wajah yang mulus. Penampilan perempuan yang seperti itu hanya bisa didapatkan setelah memakai produk kosmetik yang ditawarkan. Berbeda dengan produk kosmetik pada umumnya dalam iklan kosmetik Sophie Paris "Natural\&Halal" ini justru menampilkan Perempuan yang menggunakan hijab. Disini jelas sekali dalam iklan tersebut ada tujuan yang memanfaatkan Perempuan berhijab untuk menarik konsumen dari latarbelakang muslimah.

Keuntungan yang diperoleh dari iklan melalui media massa yakni digunakan untuk menciptakan citra merek dan daya tarik simbolis bagi suatu perusahaan atau merek terutama produk yang iklannya sangat dikenal masnyarakat. Pemilihan iklan kosmetik 
Diterbitkan oleh Program Studi IImu Komunikasi

Universitas Ahmad Dahlan Yogyakarta

Sophie Paris "Natural \& Halal"sebagai objek penelitian dikarenakan iklan Sophie Paris "Natural \& Halal" menggunakan brand ambassador yang mempunyai nilai inspiratif dan mengenakan hijab. Berbeda dengan iklan kosmetik lain yang selalu menggunakan perempuan dewasa dengan perempuan dewasa sebagai modelnya. Iklan yang satu ini meggunakan perempuan dewasa dan anak-anak sebagai modelnya. Lebih menariknya lagi anak-anak dalam iklan ini adalah anak-anak sekolah. Dibuktikan dari baju yang dikenakan anak-anak terlihat menggunakan seragam sekolah (Indriyani, 2016). Penelitian ini penting dilakukan karena iklan adalah salah satu produk media massa yang digunakan sebagai media pemasaran. Ketika iklan menggunakan Perempuan berhijab sebagai model iklannya, maka akan mengubah pandangan masyarakat terhadap Perempuan berhijab. Dalam hal ini, pandangan yang ditonjolkan adalah iklan yang menggunakan Perempuan berhijab (Morissan, 2010).

Dari latar belakang diatas, maka penelitian ini meneliti bagaimanakah komodifikasi hijab dalam iklan kosmetik Sophie Paris "Natural \& Halal"?. Penelitian ini bertujuan untuk menegaskan bahwa memang terdapat komodifikasi yang bertujuan untuk menarik minat konsumen kosmetik dalam meningkatkan penjualan. Dari gagasan tersebut dapat dibuktikan menggunakan metode kualitatif dengan analisis semiotika milik Charles S. Pierce. Penulis berharap hasil penelitian ini dapat bermanfaat sebagai kajian ilmu komunikasi yang berkaitan dengan komodifikasi periklanan, serta menambah ilmu pengetahuan mengenai dunia periklanan. Selain itu, penulis berharap agar hasil analisa ini dapat memberikan masukan tentang pentingnya komodifikasi hijab dalam iklan kosmetik, serta sebagai acuan atau referensi tentang adanya komodifikasi hijab dalam iklan kosmetik (Vera, 2014).

\section{B. Telaah Pustaka}

\section{Komodifikasi Agama: Perubahan Nilai Ideologi menjadi Nilai Ekonomi}

Peneliti dalam meneliti ekonomi politik media memiliki tugas untuk menjelaskan tentang gambaran media dengan permasalahan ekonomi pada lembaga media. Gambaran media disini adalah bagaimana media itu menggambarkan secara keseluruhan tentang apa saja yang terjadi pada media yang berkaitan dengan ekonomi pada lembaga media. Permasalahan ekonomi yang dimaksud di sini adalah keuangan yang didapat media dari pengiklan-pengiklan produk.

Kajian mengenai ekonomi-politik media dilandasi oleh pemikiran yang dikemukakan Rusadi, (2013) bahwa letak kekuatan media berada pada struktur dan proses ekonomi politik media dalam memproduksi pesan. Ekonomi politik media ini berfokus pada masalah yang berkaitan dengan persoalan ekonomi dalam memproduksi isi media, misalnya kondisi kinerja keuangan yang menurun akan memengaruhi proses perancangan isi media. Kinerja keuangan sangat memiliki andil besar dalam memajukan industri pertelevisian. Jika kinerja keuangan tidak berjalan baik maka berdampak pada rating media tersebut. Isi media diproduksi agar menaikkan rating media sehingga keuangan media akan tetap setabil. Caranya dengan membuat program menjadi lebih menarik untuk menarik. 
Tugas lain ekonomi politik media adalah untuk menguji setiap hambatan yang ada terhadap kebebasan untuk bisa mengakses produk budaya. Menurut Murdock ada dua jenis hambatan yakni material dan budaya. Hambatan material adalah alat-alat yang digunakan untuk mengakses informasi seperti televisi, radio, internet, dll. Dalam menggakses informasi kita membutuhkan biaya, misalnya Internet membutuhkan kuota untuk bisa mengakses informasi. Selain itu kita juga membutuhkan alat seperti telephone genggam untuk mengakses informasi. Televisi juga merupakan alat untuk mendapatkan informasi yang membutuhkan biaya. Untuk media cetak seperti koran kita juga harus membeli koran terlebih dahulu baru bisa menikmati informasi yang disajikan. Untuk menikmati semua itu membutuhkan biaya. Sedangkan hambatan budaya dalam mengonsumsi produk adalah regulasi yang membolehkan atau tidak membolehkan mengakses produk tertentu (Triyono, 2012).

Ekonomi politik media memiliki kerangka kerja teoreti, yaitu komodifikasi (suatu proses dimana nilai guna barang menjadi nilai tukar rupiah), spesialisasi (bagaimana cara media mengemas produknya di depan penonton dan dibatasi oleh ruang dan waktu) dan strukturasi (hubungan antara ide yang dimiliki masyarakat, proses dan praktik sosial dikemas dalam analisis struktur) dimana ketika kerangka kerja tersebut saling berkaitan dimana komodifikasi sebagai awalan atau titik masuk dalam kajian ekonomi-politik. Komodifikasi merupakan pertukaran nilai barang menjadi nilai rupiah, sedangkan spesialisasi adalah merupakan suatu proses dalam menyelesaikan kendala ruang dan waktu untuk mempperluas jangakauan suatu media agar mendapatkan keuntungan yang lebih sehingga bisa meningkatkan keuangan perusahaan media. Strukturisasi adalah struktur dan human agency yang saling berkaitan sehingga menjamin kelangsungan suatu media (Rusadi, 2013).

Komodifikasi menurut Vincent Moscow dalam penelitian Febriany, (2013) digambarkan sebagai cara kapitalisme dengan membawa akumulasi tujuan kapitalnya atau mudahnya dapat digambarkan sebagai sebuah perubahan nilai guna menjadi sebuah nilai tukar. Sebuah barang dinilai tak lagi kemampuannya memenuhi kebutuhan seseorang melainkan dinilai dengan apa yang akan dibawanya ke ranah pasar. Dengan demikian, komodifikasi yang dimaksud oleh peneliti adalah tranformasi nilai guna agama menjadi nilai tukar, dengan menggunakan fungsi nilai-nilai agama yang disesuaikan dengan kebutuhan manusia, serta dijadikan sebagai nilai tukar beberapa pergantian fungsi nilai agama tersebut sebagai alat bantu meningkatkan brand angka penjualan produk kosmetik Sophie Paris “Natural \& Halal”melalui iklan televise (Riana, 2014). Kaitannya komodifikasi dan komunikasi dapat digambarkan dari dua dimensi hubungan antara lain:

1. Proses komunikasi dan teknologi tersebut memiliki kontribusi terhadap proses umum komodifikasi secara keseluruhan.

2. Proses komodifikasi secara keseluruhan menekankan proses komunikasi dan institusinya yang terjadi dalam masyarakat. Jadi perbaikan dan bantahan dalam proses komodifikasi sosial mempengaruhi komunikasi sebagai praktik sosial. 
Diterbitkan oleh Program Studi IImu Komunikasi

Universitas Ahmad Dahlan Yogyakarta

Beberapa bentuk komoditas dalam komunikasi antara lain adalah:

a. Komodifikasi konten atau isi media komunikasi

Konten media yang sengaja dikemas sedemikian rupa untuk menarik publik, walaupun yang diperlihatkan itu bukanlah yang sebenarnya dan bukan menjadi kebutuhan publik.

b. Komodifikasi audiens

Audiens dimanfaatkan sebagai komoditi oleh pengelola media untuk mendapatkan iklan dan keuntungan yanng besar. Atau bisa disebut menjual rating.

c. Komodifikasi pekerja

Memanfaatkan tenaga dan pikiran para pekerja secara optimal dengan cara mengkonstruksi pikiran mereka bagaimana menyenangkannya jika bekerja dalam sebuah instansi media massa, walaupun dengan upah yang sangat minim dari yang seharusnya didapatkan (Setyawati, 2014).

Komodifikasi agama merupakan konstruksi historis dan kultural yang kompleks, sekalipun demikian ciri komersial mereka begitu nyata. Mereka direproduksi dalam konteks kebudayaan tertentu dan kemudian mempersyaratkan kerangka kultural untuk mempertegas signifikasi simbolik dan sosio-ekonomi mereka. Komodifikasi merupakan sebuah proses yang benar-benar diciptakan dan disertakan dalam saluran ekonomi pasar lokal-global dan ledakan agama postmodern. Komodifikasi memang tidak bertjuan memproduksi bentuk dan gerakan agama baru yang berlawanan dengan keyakinan dan praktik agama sebelumnya, namun komodifikasi akan mendudukkan agama sebagai barang yang melaluinya fungsi spiritual agama menjadi komoditas yang layak dikonsumsi dalam masyarakat (Riana, 2014).

Pada tayangan iklan televisi terjadi proses komodifikasi konten media. Lewat rekontruksi realitas melalui penggunaan model perempuan berhijab sebagai bintang utama di iklan tersebut. Dengan Notabane masyarakat Indonesia memeluk agama Islam, iklan kosmetik Sophi Paris "Natural\&Halal” mencoba menjual pesanyya pada khalayak. Agar pesan yang dikomunikasikan dan dipromosikan dalam iklan televisi tersebut dapat diterima oleh pasar. Terlepas dari hal tersebut, komodifikasi agama di iklan televisi tetap berlangsung, terbukti dengan iklan kosmetik Sophie Paris yang ditanyangkan di televisi (Riana, 2014).

\section{Konstruksi Realitas Hijab dalam Iklan}

Realitas yang ditampilkan dalam iklan di televisi bukanlah hal yang sebenarnya terjadi dalam kehidupan pemirsa, melainkan adalah hasil dari kontruksi (contruction) sebuah media yang memang dibuat untuk kepentingan dalam memenuhi berbagai keinginan dari masyarakat. Peter L Berger dan Thomas Luckman mendeskripsikan tentang teori konstruksi realitas ini. Teroi realitas menggambarkan proses sosial melalui tindakan interaksinya, di mana individu secara intens menciptakan suatu realitas yang 
dimiliki dan dialami secara subjectif. Manusia dan masyarakat adalah produk yang dialektis, dinamis, dan plural secara terus menerus (Marhaeni, 2010).

Menurut Bungin realitas sosial merupakan kontruksi sosial yang diciptakan oleh individu. Individu adalah manusia bebas yang melakukan hubungan antara manusia yang satu dengan yang lainnya individu menjadi penentu dalam dunia sosial yang dikontruksi berdasarkan kehendaknya. Individu bukanlah sosok korban sosial, namun merupakan sebagai mesin produksi sekaligus reproduksi yang kreatif dalam mengkontruksi dunia sosial (Fitri, 2015).

Perempuan adalah masyarakat sosial yang seringkali diobjektifikasi, dijadikan sasaran dalam berbagai bentuk. Komodifikasi terhadap estetika tubuh perempuan dalam iklan merupakan salah satu bentuk komodifikasi terhadap estetika tubuh perempuan, dan objektifikasi perempuan secara keseluruhan. Perempuan berhijab memiliki keindahan yang sangat luar biasa dari keindahan tubuh yang diciptakan bermacam-macam bentuknya. Semua orang kagum akan keindahan yang dimiliki setiap perempuan. Bersamaan berjalannya waktu dengan munculnya media televisi. Perempuan dibentuk seolah-olah yang cantik itu adalah perempuan yang berkulit putih, tinggi, dan langsing sehingga di dalam benak perempuan saat ini sudah tertanam bahwa perempuan cantik itu harus putih, tinggi, dan langsing. Semua terbentuk dari pengaruh media yang sudah membuat perempuan dinilai seperti itu. Pengaruh yang dihasilkan media tersebut sangat kuat tertanam di pikiran masyarakat luas sehingga masyarakat itu memiliki pandangan yang salah, karena masyarakat tidak mencerna informasi yang ia dapat dengan baik. Media pun dengan mudah memasuki pikiran masyarakat dan mempengaruhi masnyarakat dengan tayangan iklan yang disajikan. Perempuan selalu membawa perasaannya untuk menilai sesuatu. Padahal dalam iklan selalu mencari celah bagaimana perempuan bisa terpengaruh oleh iklan yang mereka iklankan (Bestari, 2013).

Iklan merupakan suatu bentuk promosi yang paling dikenal dan paling banyak dibahas orang. Hal ini mungkin karena daya jangkauan iklan yang luas. Iklan sangat cepat mempengaruhi masyarakat dalam pembelian produk. Apalagi jika pengemasan iklan tersebut tertata rapi dan mengena dihati masyarakat pasti akan banyak orang yang tertarik oleh iklan tersebut(Morissan, 2010).

Iklan menampilkan perempuan cantik dengan wajah yang sempurna. Iklan tidak akan lari jauh dari kesempurnaan setiap orang entah itu lelaki atau perempuan pasti yang dicari yang memiliki tubuh yang sempurna, sebab yang sempurnalah yang menjual. Setiap iklan produk biasanya menampilkan Perempuan sebagai objeknya. Contohnya, iklan parfum Axe versi Heaven On Earth dimana iklan ini menonjolkan perempuan sebagai objek utamanya (Akhmad, 2013). Sehingga masyarakat cenderung menilai perempuan menarik untuk dijadikan bintang utama dalam iklan dibandingkan dengan seorang laki-laki. Perempuan mempunyai tempat yang fungsional dari pada laki-laki. Citra pigura menunjukkan bahwa penting bagi perempuan berhijab untuk tampil dengan memikat. Untuk mencapai itu, perempuan berhijab harus mengukuhkan keperempuanannya secara biologis dan budaya. Tuntutan untuk tampil awet muda, langsing, dan memiliki kulit yang putih sangat dominan dalam iklan-iklan yang ditunjukkan bagi perempuan. Bahkan para remaja putripun sudah terinternalisasi atas nila-nilai kecantikan itu. Hasil yang dilakukan oleh jurnal perempuan terhadap seratus remaja putri yang 
Diterbitkan oleh Program Studi IImu Komunikasi

Universitas Ahmad Dahlan Yogyakarta

bertema "Remaja Putri Melek Media" mengungkapkan bahwa 57 \% responden setuju atas pernyataan bahwa cantik itu berkulit putih, berambut lurus panjang dan berbadan langsing (Santi, 2012).

Perempuan berhijab menempati posisinya dalam kapitalisme wajah baru. Dimulai dengan gambaran dari perdebatan antara cendekiawan Muslim tradisional dan feminis Muslim tentang apakah jilbab adalah kewajiban Islam. Ini menerangi pentingnya ruang, sebagai praktik berjilbab yang sangat terlibat dan tertanam dalam praktek tata ruang dibentuk oleh konteks Skotlandia lokal. Bentuk baru ini menjadikan semua hal adalah tanda-tanda yang bisa dikomodifikasi. Dalam hal ini hijab menjadi salah satu tanda dari bentuk komoditas yang dapat dikonsumsi dan bisa dilihat siapa saja. Selain itu perempuan dalam sisi ekonomi tubuhnya digunakan dalam berbagai aktivitas yang menjadi gambaran sosial (Siraj, 2011).

Komodifikasi adalah suatu nilai tukar barang menjadi nilai tukar rupiah yang memanfaatkan sesuatu. Komodifikasi adalah titik masuk awal untuk menteorisasikan ekonomi politik komunikasi (Ibrahim, 2014). Hubungan antara perempuan dan komodifikasi terjadi pada saat perempuan dijadikan sebuah objek untuk meraup keuntungan, misalnya perempuan yang ditampilkan diiklan-iklan itu selalu perempuan yang memiliki tubuh yang bagus dan pasti putih. Disini perempuan dijadikan sebagai penarik keuntungan bagi perusahaan yang mengiklankan suatu barang. Perempuan seolah-olah adalah ladang emas untuk suatu perusahaan, maksudnya perempuan yang menghasilkan banyak keuntungan untuk perusahaan, karena perempuan disini dijadikan sebagai model iklan suatu perusahaan. Dengan menggunakan perempuan yang cantik, putih, memiliki tubuh yang bagus. Ini bisa menarik konsumen untuk membeli suatu produk yang ditawarkan ke konsumen. Banyaknya masyarakat yang tertarik dengan produk yang diiklankan juga berpengaruh pada peningkatan keuangan perusahaan sehingga perusahaan bisa mendapatkan keuntungan yang sangat besar.

\section{Metode}

\section{Metode Penelitian}

Dalam penelitian ini, peneliti menggunakan pendekatan kualitatif sebagai metode penelitian. Hal ini didasarkan pada penelitian peneliti untuk mengidentifikasi data yang diperoleh dari tayangan iklan tentang penggunaan hijab dalam iklan Sophie Paris. Kualitatif sendiri ialah sebagai prosedur penelitian yang menghasilkan data deskriptif berupa kata-kata tertulis atau lisan dari orang-orang dan perilaku yang dapat diamati. Metodelogi kualitatif ialah suatu tradisi tertentu dalam ilmu pengetahuan sosial yang secara fundamental bergantung pada manusia dalam kawasannya sendiri dan dalam peristilahannya (Sugiyono, 2008).

\section{Subjek dan Objek Penelitian}

a. Subjek penelitian adalah sumber data dari penelitian yang dimana data itu diperoleh (Arikunto, 2013). Subjek dalam penelitian ini adalah iklan kosmetik Sophie Paris versi "Natural \& Halal”. 
b. Objek penelitian, yaitu masalah apa yang hendak diteliti atau masalah penelitian yang disajikan oleh peneliti, pembatasan yang dipertegas dalam penelitian (Indriyani, 2016). Objek dalam penelitian ini adalah komodifikasi hijab dalam iklan televisi kosmetik Sophie Paris, serta pemaknaan komodifikasi simbol hijab dalam iklan kosmetik Sophie Paris "Natural \& Halal”.

\section{Unit Analisis}

Unit analisis adalah satuan terkecil yang diteliti. Unit analisis dapat berupa kelompok, perseorangan maupun data-data (Rahmanti, 2013). Sesuai dengan judul penelitian ini, yaitu komodifikasi hijab dalam iklan kosmetik sophie paris versi "Natural \& Halal" di televisi maka yang menjadi unit analisisnya adalah iklan kosmetik Sophie Paris "Natural\&Halal", dengan durasi 30 detik, yang telah tayang di televisi Indonesia sejak 10 Juli 2014.

\section{Teknik Pengumpulan Data}

Teknik pengumpulan data dalam penelitian ini berupa dokumentasi. Untuk mendapatkan iklan kosmetik Sophie Paris peneliti melihat tayangan iklan di televisi kemudian mengkopi file dari situs internet. Iklan inilah yang selanjutnya dijadikan bahan untuk menganalisis penelitian ini. Untuk melengkapi data penelitian digunakan pula studi kepustakaan untuk mencari referensi sesuai dengan tujuan penelitian (Jayanti, 2014).

Teknik pengumpulan data yang akan dilakukan melalui:

a. Dokumentasi

Dokumen merupakan catatan peristiwa yang sudah berlalu. Dokumen bisa berbentuk tulisan, gambar, atau karya-karya monumental dari seseorang. Dokumentasi dalam penelitian ini adalah iklan Kosmetik Sophie Paris "Natural \& Halal” yang diambil dari situs youtube (Sugiyono, 2008).

b. Studi Pustaka

Dalam melakukan penelitian ini menggunakan beberapa buku atau jurnal yang terkait dengan penelitian komodifikasi, periklanan, hijab.

\section{Analisis Data}

Pada penelitian ini digunakan teknik analisis semiotika milik Charles S. Pierce, karena penelitian ini hampir memiliki kesamaan dengan teori Pierce, dimana sama-sama mengidentifikasi tanda dan makna dengan menggunakan trianggel of meaning. Charles S. Peirce mengatakan bahwa tanda merupakan perwakilan dari suatu hal yang mana suatu hal tersebut adalah interpretan yang mengacu pada objek tertentu. Sehingga fungsi analisis semiotika dalam penelelitian ini bersifat nyata dan menghubungkan antara tanda tersebut dengan objeknya (Wibowo, 2013). 
Diterbitkan oleh Program Studi IImu Komunikasi

Universitas Ahmad Dahlan Yogyakarta

Gambar Skema 1: Segitiga Makna Pierce

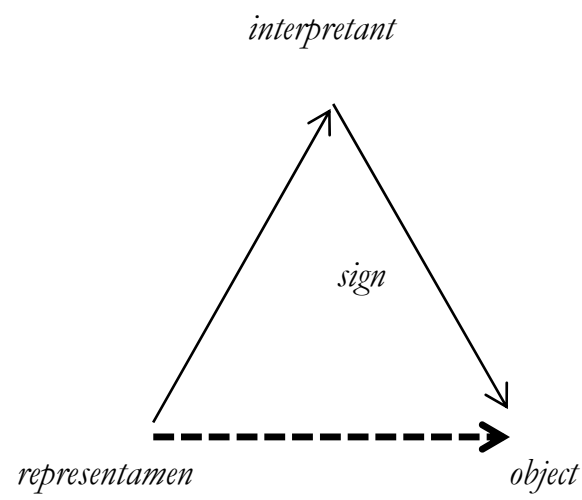

Sumber: Semiotika Komunikasi (Vera, 2014)

Penggunaan tipologi ini untuk membedah iklan niaga kosmetik Sophie Paris. Dimana peneliti memaknai gambar dari iklan tersebut akan lebih mudah karena dibantu oleh analisa dari Charles S Peirce. Nanti di setiap adegan pada iklan diartikan dengan maknanya sendiri-sendiri barulah dianalisis atau dapat menggunakan model triadik dari Peirce dimana sering disebut sebagai "triangle meaning semiotics" atau dikenal dengan teori segitiga makna, yang dijelaskan secara sederhana (Guna, 2014).

Peneliti memilih menggunakan analisis semiotika, karena memiliki tujuan untuk memahami tanda dan cara kerjanya ke dalam tiga kategori model dari Charles S Peirce. Model dari Peirce ini memiliki versi tanda yang disebut tipologi tanda dengan tiga tipe tanda yakni, Ikon adalah tanda yang berhubungan antara penanda dan petandanya bersifat bersamaan bentuk alamiah. Dengan kata lain, ikon adalah hubungan antara tanda dan objek atau acuan yang bersifat kemiripan, misalnya; potret dan peta. Indeks adalah tanda yang menunjukan adanya hubungan alamiah antara tanda dan petanda yang bersifat kausal atau hubungan sebab akibat, atau tanda yang langsung mengacu pada kenyataan. Contoh yang paling jelas adalah asap sebagai tanda adanya api. Tanda dapat pula mengacu ke denotatum melalui konvensi. Tanda seperti itu adalah tanda konvensional yang biasa disebut simbol. Jadi simbol adalah tanda yang menunjukkan hubungan alamiah antara penanda dengan petandanya. Hubungan diantaranya bersifat arbitrer atau semena, hubungan berdasarkan konvensi (perjanjian) masyarakat (Sobur, 2004).

Charles S Pierce membagi tanda dan cara kerjanya kedalam tiga katagori yang terlihat pada tabel di bawah. Mesti begitu dalam praktiknya, tidak dapat dilakukan secara 'mutually exclusive' sebab dalam konteks-konteks tertentu ikon dapat menjadi simbol. Banyak simbol yang berupa ikon. Disamping menjadi indeks sebuah tanda juga berfungsi sebagai simbol.

Berdasarkan teori yang dikembangkan oleh Pierce, tanda-tanda dalam gambar digolongkan dalam ikon, indeks dan simbol. Berdasarkan segitiga makna yang dikembangkan oleh pierce ini maka tahapan-tahapan yang dilakukan dalam analisis semiotik yang dilakukan oleh penulis adalah sebagai berikut:

a. Mengidentifikasi tanda-tanda komodifikasi hijab yang terdapat pada iklan kosmetik Sophie Paris Versi "Natural \& Halal" di Televisi 
b. Menginterprestasikan satu persatu jenis tanda yang telah diidentifikasi dalam iklan tersebut.

c. Memaknai secara keseluruhan mengenai Komodifikasi Hijab pada iklan kosmetik Sophie Paris Versi "Natural \& Halal" Di Televisi berdasarkan hasil interprestasi terhadap tanda yang telah diidentifikasi sebelumnya sehingga dapat ditarik kesimpulan (Indriyani, 2016).

\section{Teknik Keabsahan Data}

Teknik keabsahan data dalam penelitian, sering ditekankan pada uji validitas dan reabilitas. Validitas merupakan derajad ketepatan antara data yang terjadi pada objek penelitian dengan daya yang akan dilaporkan oleh peneliti. Validitas ini menunjukkan bahwa penelitian itu asli dan ada pembuktiannya yang akurat. Bukan hanya sekedar melakukan penelitian begitu saja tapi dijamin keakuratan dataya. Selain itu juga terdapat dua macam validitas penelitian, yakni validitas internal dan validitas eksternal. Validitas internal berkenaan dengan derajad akurasi desain penelitian dengan hasil yang dicapai. Sedangkan validitas eksternal berkenaan dengan derajat akurasi apakah hasil penelitian dapat digeneralisasikan atau diterapkan pada populasi dimana sampel tersebut diambil. Teknik pemeriksaan keabsahan data, peneliti menggunakan teknik trianggulasi data, yaitu teknik pengumpulan data yang bersifat menggabungkan dari berbagai teknik pengumpulan data dan sumber data yang sudah ada (Bachri, 2010).

Peneliti melakukan penelitian menggunakan triangulasi data yaitu untuk mendapatkan data dari sumber yang berbeda-beda dengan teknik yang sama. Trianggulasi data dipilih oleh peneliti sebagai validitas data karena penelitian ini berfokus pada penelitian kualitatif, yang berdasarkan pada analisis semiotika pada iklan kosmetikSophie Paris "Natural \& Halal". Instrumen riset utama disini adalah peneliti sendiri. Disini peneliti mengcroscheek hasil penemuan data dengan dokumen-dokumen yang terkait dengan penelitian. Dokumen yang didapat dari berbagai data yakni, jurnal, skripsi, youtube, dan buku-buku yang berkaitan dengan penelitian. Data dokumentasi yang dimaksut disini adalah data-data yang digunakan untuk menggali informasi yang berkaitan tentang iklan kosmetik. Peneliti melihat dan mengamati iklan kosmetik kemudian mencatat dan menganalisis data tersebut. Sehingga peneliti menemukan hasil yang diinginkan dan mendapatkan kevaliditasan data yang benar-benar keakuratannya (Sugiyono, 2008)

\section{Analisis dan Pembahasan}

Hasil gambar-gambar yang terdapat dalam iklan kosmetik memiliki tanda-tanda yang menghasilkan pesan komodifikasi. Dengan menggunakan segitiga makna atau triangle of meaning oleh Charles $\mathrm{S}$ Pierce yang memperlibatkan tiga elemen pembentukan tanda, yaitu tanda atau representamen, objek dan interpretan. Iklan kosmetik Sophie Paris merupakan salah satu iklan yang mengedepankan perempuan berhijab sebagai faktor terpenting. Iklan Sophie Paris menampilkan fashion yang bagus untuk menarik konsumen sebagai acuan mode. Namun, tak hanya penawaran kosmetik saja yang diterima oleh pemirsa dirumah. Jika dikaji dari sisi semiotik terdapat gambaran 
Diterbitkan oleh Program Studi IImu Komunikasi

Universitas Ahmad Dahlan Yogyakarta

erempuan berhijab yang dikomodifikasikan sedemikian rupa guna menjadi daya tarik terhadap program tersebut (Guna, 2014).

Bedanya iklan ini dengan iklan yang lain, yaitu selama ini iklan kosmetik itu selalu menggunakan perempuan dewasa sebagai model utamanya dan peran pembantu. Tetapi dalam penelitian ini iklan menggunakan perempuan dewasa sebagai pemeran utamanya dan anak-anak sekolah sebagai peran pembantu.

Setelah melakukan pengamatan dari hasil penelitian, peneliti dapat menganalisa dari apa yang penulis telah teliti dari potongan-potongan gambar pada iklan Sophie Paris tentang unsur komodifikasi pada iklan televisi.

\section{Gaya Hidup Halal}

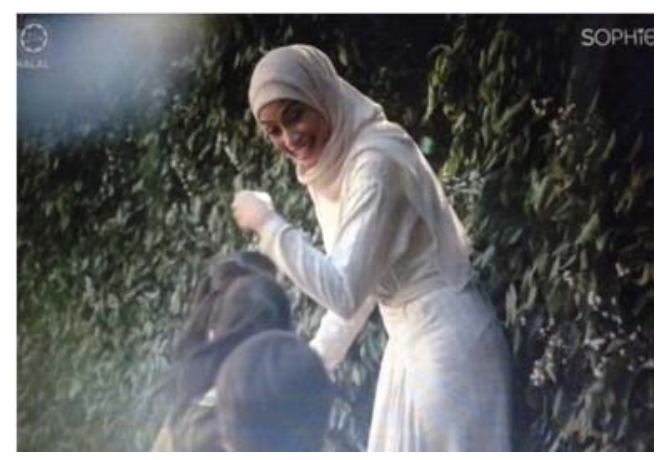

Gambar 1. Seorang perempuan berhijab sedang mengarahkan anak-anak

Pada Scene satu ini, terlihat seorang perempuan menggunakan busana tertutup lengkap dengan kerudung sedang berdiri sedikit membungkuk dengan tangan kiri diangkat dan diarahkan ke samping kanan seraya tersenyum kepada tiga orang anak kecil, terdiri dari dua anak perempuan dan satu anak laki-laki yang sedang berlari. Diperkuat dengan bacground tanaman berdaun hijau serta logo halal dan nama perusahaan di pojok atas kanan dan kiri (Jayanti, 2014).

Keberadaan perempuan berhijab merupakan suatu keuntungan yang sangat besar dalam industri kapitalis. Meskipun perwujudan komoditas tersebut hanyalah pendefinisian manusia yang mengambil wujud fantastis dari suatu hubungan di antara benda-benda hasil produksi. Hal tersebut dikarenakan peran media yang kerap menawarkan ilusi-ilusi mengenai sebuah citra dari gaya hidup (Guna, 2014). Citra yang ditampilkan dalam kebanyakan iklan yang ada di televisi menunjukkan bahwa perempuan itu harus tampil mimikat. Untuk menjadi cantik perempuan hijab mengukuhkan kemuslimahannya secara biologis dan budaya. Iklan dituntut harus memiliki penampilan yang menarik. Seorang perempuan saat ini harus berpenampilan yang modern dan mengikuti tred yang sedang berkembang di dunia ini. Bahkan para muslimah pun sudah sangat terinternilaisasi atas nilai-nilai kecantikan itu. Citra seorang muslimah dalam iklan televisi menggambarkan sebuah ilusi yang disebarkan melalui iklan (Santi, 2012).

Ilusi dari tayangan tersebut yakni menggambarkan sosok perempuan dengan kecantikan yang sesungguhnya yang terpancar dari dalam hati, yaitu berupa kelembutan. Kemudian adegan yang dilakukan dalam scene ini berupa seorang perempuan berhijab yang sedang tersenyum mengarahkan anak-anak dengan sabar. Scene ini, menampilkan 
tiga murid sekolah yang sedang bermain dengan gurunya. Dibuktikan dari seragam yang dipakai oleh tiga anak tersebut. Dalam iklan tersebut tidak hanya mengunakan perempuan berhijab saja untuk menarik konsumen, akan tetapi disini juga menggunakan anak-anak untuk mendukung iklan tersebut agar terlihat lebih menarik dan dapat mendongkrak iklan. Dimana yang sangat ditonjolkan adalah perempuan berhijab. Kemudian diperkuat dengan ucapan sang narator yang mengatakan "kecantikan", hal ini menandakan bukan hanya perempuan dengan rambut hitam, lurus, dan panjang terurai berkulit putih serta menggunakan pakaian yang seksi saja yang dikatakan cantik, namun takaran kecantikan seseorang perempuan sesungguhnya terletak pada hatinya bukan semata-mata hanya di nilai dari fisik (luar) nya saja (Jayanti, 2014). Scene satu ini memperlihatkan hijab sebagaisimbol nonverbal yang dikelola oleh perempuan berhijab. Upaya pengelolahan kesan melalui simbol non verbal yang dilakukan perempuan berhijab lebih dominan dari pada simbol secara verbal. Dalam pandangan tersebut, hijab yang merupakan bagian dari konten komodifikasi, kini telah menjadi bagian yang tak terlepaskan dari penampilan dan gaya keseharian (Talani, 2015).

Tabel 1. Perempuan Berhijab Memberikan Arahan

No.

Tipe Tanda

Representamen (X) Ikon

1. Indeks

Simbol

2. Objek $(\mathrm{Y})$

3. Interpretant $(\mathrm{X}=\mathrm{Y})$

4. Makna

\section{Data}

Iklan tersebut memperlihatkan perempuan berhijab yang sedang berjalan disebuah labirin dengan memiringkan sedikit kepalanya sambil tersenyum dan diperkuat dengan background tanaman berdaun hijau rimbun.

-Ekspresi wajah sedang tersenyum.

-Menjadi tanda bahwa dalam iklan ini terdapat komodifikasi. Dimana perempuan hijab dikemas seolah-olah memiliki kecantikan dari dalam hati.

Perempuan berhijab

Menunjukan bahwa perempuan yang memiliki hati lembut dan di sukai anak-anak

Gambaran perempuan dengan pribadi yang penyayang memperlihatkan kemurnian dari kecantikan seorang perempuan.

Sumber: Data Sekunder (Jayanti, 2014) 
Diterbitkan oleh Program Studi IImu Komunikasi Universitas Ahmad Dahlan Yogyakarta

\section{Konsumerisme}

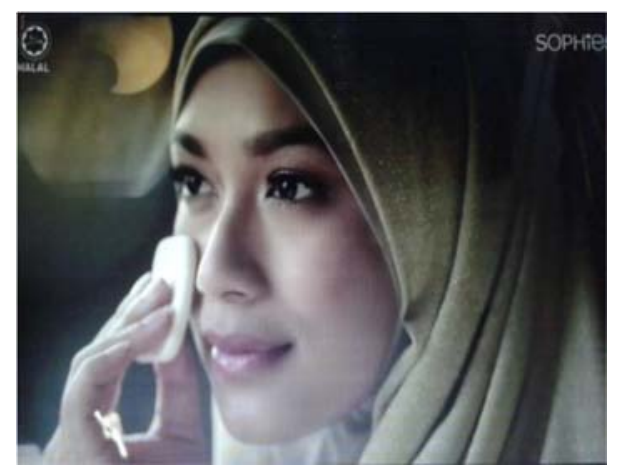

Gambar 2. Seorang perempuan sedang menempelkan spon bedak di pipinya

Pada Scene enam ini terlihat perempuan berhijab sedang melakukan aktivitas mengangkat tangan kanannya sejajar dengan pipi selanjutnya menempelkan spon bedak di pipinya dengan tatapan yang lurus dan sedikit tarikan pada garis bibirnya. Dalam tayangan ini memaknai bahwa pada kodratnya wanita ingin terlihat menarik disegala situasi, ingin dihargai, serta ingin dan senang diperhatikan Scene ini memperlihatkan aktivitas mempercantik diri yaitu dengan berdandan namun tidak dengan cara yang berlebihan Karena sesuatu yang dilakukan secara berlebihan akan menghasilkan sesuatu yang tidak baik juga pada akhirnya. Kemudian diperkuat dengan pernyataan sang narator yang mengatakan "untuk mewarnai". Maksud potongan kalimat tersebut adalah kegiatan mempercantik diri dengan berdandan seperti yang dilakukan perempuan pada umumnya dalam menunjang penampilan secara fisik, karena kecantikan fisik berupa ilahilah dan bermakna mistis memiliki karakter individual yang terpahat disana. Kemudian, tatapan lurus serta penuh keyakinan yang diperlihatkan oleh model wanita pada gambar diatas, menunjukkan kepercayaan diri untuk tetap tampil cantik walau hanya dengan berdandan secara sederhana (Jayanti, 2014).

Seperti dalam iklan ini, terdapat nilai-nilai yang ingin dikomunikasikan atau dipromosikan melalui apa yang ditampilkan. Iklan ini menampilkan kehidupan seharihari perempuan berhijab dengan menggunakan riasan wajah yang terlihat natural, selain itu juga ditampilkan perempuan yang sedang memakai bedak dengan wajah yang berseri seri. Sudah jelas bahwa perempuan berhijab dalam iklan ini hanya dijadikan sebagai alat komodifikasi untuk menarik minat pembeli. Iklan sendiri tidak menyadari bahwa iklan yang mereka produksi mengandung nilai komodifikasi. Meskipun sebenarnya wujud dari komoditas tersebut hanyalah pendefinisian manusia yang mengambil wujud fantastis dari suatu hubungan di antara benda-benda hasil produksi (Guna, 2014). Itulah mengapa dalam iklan kosmetik Sophie Paris, menggunakan Perempuan berhijab yang menjadi sebuah bahan yang menarik untuk ditampilkan dan dikomodifikasikan. 
Tabel 2.Perempuan Sedang Menempelkan Spon Bedak di Pipinya

No.

\begin{tabular}{ll} 
& $\begin{array}{l}\text { Representamen }(\mathrm{X}) \\
\text { Ikon }\end{array}$ \\
1. Indeks & \\
& \\
& Simbol \\
& \\
\hline 2. & \\
3. & Objek $(\mathrm{Y})$ \\
4. & Makna
\end{tabular}

\section{Data}

Terlihat seorang perempuan berhijab yang sedang menempelkan spon bedak di pipinya dengan tatapan yang lurus dan sedikit tarikan pada garis bibirnya.

-Adegan mengangkat tangan sejajar dengan pipi -Menjadi tanda sedang melakukan aktivitas memprcantik diri secara fisik, yaitu dengan berdandan.

Suara narator yang mengucapkan "untuk mewarnai" menggambarkan bahwa bersolek untuk mendapatkan kecantikan sah-sah saja namun tetap pada tahap kesederhanaan.

Wajah model wanita berhijab

Mempercantik wajah dengan menggunakan bedak.

Perempuan berdandan demi memperoleh kecantikan pada tahap yang diperlukan akan menambah kecantikan yang diidamkan

Sumber: Data Sekunder (Jayanti, 2014)

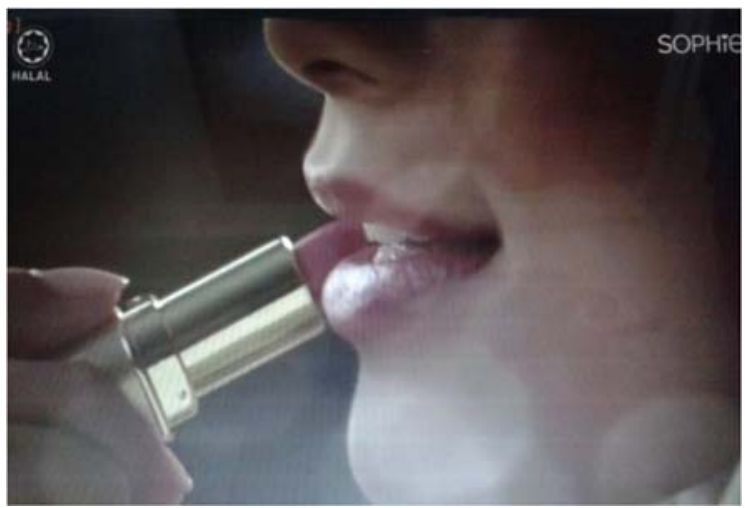

Gambar 3 Seorang perempuan sedang memakai lipstik

Pada scene tujuh ini terlihat potongan wajah dengan fokus perhatian pada bibir bagian atas dan bawah yang terlihat dari bagian samping kiri serta jari tangan yang sedang memegang pensil bibir berwarna merah muda dengan kuku yang diberi cat warna merah muda. Gambar close-up diatas menunjukkan bahwa produk kosmetik yang dibuat khusus untuk jenis kulit didaerah tropis ini benar-benar sesuai jika digunakan agar tetap terlihat cantik dalam menunjang aktivitasnya sehari-hari. Namun, potongan gambar di atas juga memperlihatkan kuku berwarna merah muda, di mana dalam Islam, penggunaan pewarna kuku (kutek) untuk perempuan berhijab pada dasarnya hanya diperbolehkan ketika seorang perempuan sedang tidak menjalankan kewajiban sebagai umat Islam. Selanjutnya, terdengar suara narator yang mengatakan "untuk melindungi dan menjaga kecantikanmu". Potongan kalimat tersebut diatas menandakan bahwa dengan menggunakan kosmetik bersertifikasi halal yang terbuat dari bahan-bahan alami berkualitas ini akan dapat melindungi kulit dari sinar matahari langsung, debu, dan asap kendaraan sertaakan membuat kecantikan seseorang akan tetap terjaga sepanjang hari walau sesibuk apapun kegiatannya (Jayanti, 2014). Setiap iklan ini terlihat merendahkan 
Diterbitkan oleh Program Studi IImu Komunikasi

Universitas Ahmad Dahlan Yogyakarta

derajat seorang wanita muslimah, hal ini dijelaskan dengan visual yang ada dan dialog di dalam iklan ini. Iklan ini membuat seolah-olah berrias itu adalah kewajiban seorang muslimah dimana seperti yang ditampilkan pada iklan tersebut. Bukan merendahkan wanita dimata laki-laki saja tetapi juga merusak nama baik muslimah di mata banyak orang. Sudah jelas bahwa wanita muslimah dalam iklan ini hanya dijadikan sebagai alat komodifikasi untuk menarik minat pembeli (Guna, 2014).

Tabel 3.Perempuan Sedang Memakai Lipstik

\begin{tabular}{|c|c|c|}
\hline No. & Tipe Tanda & Data \\
\hline & $\begin{array}{l}\text { Representamen (X) } \\
\text { Ikon }\end{array}$ & $\begin{array}{l}\text { Close-up wajah dengan fokus perhatikan pada bibir } \\
\text { bagian atas dan bawah serta jari tangan yag seang } \\
\text { memegang pensil bibir berwarna merah muda dengan } \\
\text { kuku yang diberi warna merah muda juga. }\end{array}$ \\
\hline \multirow[t]{2}{*}{1.} & Indeks & $\begin{array}{l}\text {-Model yang menggunakan produk kosmetik muslimah } \\
\text {-Menjadi tanda kosmetik yang di komodifikasikan }\end{array}$ \\
\hline & Simbol & $\begin{array}{l}\text { Suara narator yang mengatakan "melindungi dan } \\
\text { menjaga kecantikanmu" menandakan bahwa kecantikan } \\
\text { seorang wanita dapat terjaga bila menggunakan produk } \\
\text { kosmetik muslimah. }\end{array}$ \\
\hline 2. & Objek $(Y)$ & Bibir seorang wanita dan lipstik \\
\hline 3. & Interpretant $(\mathrm{X}=\mathrm{Y})$ & $\begin{array}{l}\text { Kecantian perempuan yang akan tetap terjaga dengan } \\
\text { meggunakan produk kosmetik muslimah. }\end{array}$ \\
\hline 4. & Makna & $\begin{array}{l}\text { Perempuan yang menggunakan kosemetik muslimah } \\
\text { mampu menjaga kecantikannya. }\end{array}$ \\
\hline
\end{tabular}

Sumber: Data Sekunder (Jayanti, 2014)

Dari ketiga gambar diatas dapat dijelaskan bahwa terdapat komodifikasi pada iklan ini. Dimana iklan ini mengkomodifikasikan mengenai wanita hijab sebagai identitas seorang muslimah. Bukti dari komodifikasi wanita hijab ini dapat dijelaskan dengan visual yang ada dan diperkuat dialog, bahwa menggunakan hijab merupakan identitas seorang muslimah. Penggunaan hijab dapat digunakan untuk membedakan wanita apakah Muslim atau non Muslim. Fungsi hijab bukan hanya untuk menutup kepala tetapi dapat di simpulkan sebagai identitas seorang muslimah. Komodifikasi muslimah modern dalam iklan ini dapat ditunjukan dengan riasan wajah yang ditampilkan dalam setiap shotnya oleh model cantik bernama Karina Nadila.

Iklan Sophie Paris digambarkan dengan menampilkan nilai keagamaan untuk kepentingan pengiklan. Nilai-nilai keagamaan dalam iklan ini yang seharusnya bersifat sakral mengalami rekonstruksi makna. Di mana yang awalnya berhubungan dengan ketuhanan sekarang dialih fungsikan sebagai media periklanan yang secara jelas bersifat komersil. Dalam iklan ini Perempuan berhijab diproduksi menjadi komoditas untuk diperjual belikan melalui media periklanan yang seolah-olah layak untuk dikonsumsi masyarakat (Wahidah, 2015). Penelitian ini mengacu pada penelitian dari (Indriyani, 2016) di mana penelitiannya hampir sama dengan penelitian yang sedang diteliti oleh peneliti saat ini. Perbedaan dari penelitian ini adalah object yang diteliti. Object dari 
penelitian Indriyani ini berupa iklan Shampo Clean and Fresh di televisi, sedangkan objek dari penelitian ini adalah iklan Kosmetik Sophie Paris "Natural \& Halal”.

Proseskomodifikasiyangmuncul pada iklan Sophie Paris adalah komodifikasi konten yang dapat dilihat dari tanda-tanda dan gambaran cerita iklan tersebut. Sophie Paris mencoba menjual pesannya terhadap masyarakat luas melalui iklan ditelevisi dan menggunakan tema islami. Unsur nilai agama dalam iklan terasa sangat kuat ketika dalam iklan tersebut memunculkan visualisasi yang menyerupai dengan kenyataan kehidupan masyarakat. Dari sinilah terlihat jelas bahwa pengiklan menyiapkan materi konstruksi realitas di mana media massa berpihak kepada pemilik modal atau kapitalis. Hal ini dilakukan untuk mendapatkan keuntungan yang berlimpah sesuai yang diharapkan pengiklan (Ibrahim, 2014).

\section{E. Penutup}

Dari penelitian yang sudah dilakukan maka dapat ditarik kesimpulan bahwa hijab yang seharusnya digunakan sebagai ibadah untuk memenuhi perintah Allah bagi kaum muslimah untuk menutup auratnya, tetapi dalam kenyataanya hijab terjadi perubahan dimana nilai barang menjadi nilai tukar yang bersifat komersil yang terdapat dalam iklan kosmetik Sophie Paris “Natural\&Halal”dan Karina Nadila(Fitri, 2015)

Komodifikasi yang muncul pada iklan Sophie Paris adalah Komodifikasi isi atau konten yang terlihat dari cerita dan tanda-tanda yang ditampilkan pada iklan tersebut. Disini iklan Sophie Paris mencoba menjual pesan yang mereka sampaikan kepada khalayak melalui iklan yang ditayangkan pada televisi yang menggunakan tema Perempuan berhijab. Hijab dalam iklan ini memiliki unsur yang sangat kuat ketika dalam iklan tersebut memunculkan visualisasi yang menyerupai dengan realitas kehidupan masyarakat. Dari sinilah terlihat jelas pengiklan menyiapkan materi kontruksi realitas dengan keberpihakan media massa kepada pemilik modal atau kapitalis. Hal ini dilakukan untuk mendapatkan keuntungan yang besar sesuai yang diharapkan pengiklan (Indriyani, 2016).

Komodifikasi yang terjadi dalam iklan ini diawali dengan memasukkan konsep Perempuan berhijab ke dalam iklan. Dari iklan tersebut dihasilkan penggunaan hijab yang telah dikomodifikasikan dalam iklan Sophie Paris "Natural\&Halal". Iklan tersebut mengalami pergeseran dari nilai fungsi ke nilai tukar. Dimana nilai fungsi hijab yang seharusnya dipergunakan untuk beribadah kepada Allah, namun dalam kenyataannya dijadikan sebagai pengeruk keuntungan yang berlimpahuntuk sebuah perusahaan.

\section{Daftar Pustaka}

Akhmad, P. (2013). Representasi Sensualitas Perempuan dalam Iklan. Universitas Islam Negeri Sunan Kalijaga.

Arikunto, S. (2013). Prosedur Penelitian (Suatu pendekaTan prakTik). Jakarta. 
Diterbitkan oleh Program Studi IImu Komunikasi

Universitas Ahmad Dahlan Yogyakarta

Bachri, B. S. (2010). Meyakinkan Validitas Data Melalui Triangulasi Pada Penelitian Kualitatif. Retrieved from http://yusuf.staff.ub.ac.id/files/2012/11/meyakinkanvaliditas-data-melalui-triangulasi-pada-penelitian-kualitatif.pdf

Bestari, H. (2013). Komodifikasi Estetika Tubuh Perempuan dalam Iklan-Habiibati Bestari | 1, 1-11.

Febriany, W. L. D. (2013). Komodifikasi Anak Dalam Iklan (Analisis Semiotika Roland Barthes Pada Iklan Prudential Di Televisi Versi Mendengarkan Cita -Cita Mereka), 53(9), 1689-1699. http://doi.org/10.1017/CBO9781107415324.004

Fitri, R. (2015). Konstruksi Realitas Hijab Pada Wanita Muslimah Dalam Film "99 Cahaya Di Langit Eropa," 2(2), 1-10.

Guna, B. A. (2014). Komodifikasi Fetisisme Pada Program ILOOK di NET TV.

Hassim, N. (2014). Hijab and the Malay-Muslim Woman in Media. Procedia - Social and Behavioral Sciences,

155(October), 428-433. http://doi.org/10.1016/j.sbspro.2014.10.317

Ibrahim, I. S. dan B. A. A. (2014). Komunikasi dan Komodifikasi. Jakarta.

Indriyani, P. I. (2016). Komodifikasi hijab dalam iklan sampo sunsilk Clean andFresh di Televisi.

Jayanti, E. D. (2014). Eksploitasi hijab dalam iklan produk muslimahkosmetik Sophie Paris di televisi. Retrieved from http://repository.uinjkt.ac.id/dspace/bitstream/123456789/26864/1/ERFA DWI JAYANTI-FDK.pdf

Jenaibi, B. B. N. A. Al. (2008). The changing representation of the Arab Woman in Middle East advertising and media. Retrieved from https://www.researchgate.net/publication/283480871_The_changing_representati on_of_the_Arab_Woman_in_Middle_East_advertising_and_media

Marhaeni, D. K. (2010). Representasi Anak-Anak Dalam Tayangan Iklan Komersial Di Media, 1(1), 1-11.

Morissan. (2010). Periklanan Komunikasi Pemasaran Terpadu (pertama). Jakarta.

Pertiwi, Ade. (2015). Majalah Hijabella Dan Gaya Hidup Muslimah Dalam Mengimitasi Budaya Populer Berhijab (Studi Korelasi Pada Mahasiswi Di Kota Medan). Retrieved from http://f.123dok.com/4547-majalah-hijabella-dan-gaya-hidupdalam-mengimitasi-budaya-populer-berhijab-studi-korelasi-pada-mahasiswi-dikota-medan.htm

Rahmanti, N. N. (2013). Hijabers Community (Studi Tentang Konsumsi Dan Komodifikasi Busana Muslim Dalam Komunitas Wanita Muslimah Berhijab Di Yogyakarta).

Ratri, L. (2011). CADAR, MEDIA, DAN IDENTITAS PEREMPUAN MUSLIM. Topik Utama.

Retrieved from http://ejournal.undip.ac.id/index.php/forum/article/viewFile/3155/2832

Riana, G. V. (2014). Komodifikasi Nilai Agama Dalam Iklan Televisi (Studi Analisis Semiotik Komodifikasi Nilai Agama Terhadap Iklan Larutan Cap Kaki Tiga).

Robinson, R. S. (2015). Sexuality, Difference, and American Hijabi Bloggers, 13(3), 383-400.

Retrieved

from 
http://booksandjournals.brillonline.com/content/journals/10.1163/1569208612341289

Rusadi, U. (2013). Kajian Media (Isu Ideologis Dalam Perspektif, Teori Dan Metode). Jakarta.

Santi, S. (2012). Perempuan Dalam Iklan: Otonomi Atas Tubuh Atau Komoditi? - edit. Komoditi, 1(1). Retrieved from http://download.portalgaruda.org/article.php?article $=160732 \& \mathrm{val}=4568 \&$ title $=\mathrm{Pe}$ rempuan Dalam Iklan: Otonomi Atas Tubuh Atau Komoditi?

Setyawati, A. A. (2014). Komodifikasi Budaya Pada Tayangan Televisi (Studi Analisis Wacana Pada Tayangan Ngunduh Mantu Raffi Dan Nagita Di Rcti, 30 Desember 2014).

Shirazi, F. (2010). Islam and Barbie The Commodification of Hijabi Dolls. Retrieved from http://iranianstudies.org/wp-content/uploads/2010/04/Islamic-perspectiveJournal-number-3-2010.pdf

Siraj, A. (2011). Meanings of Modesty and the Hijab Amongst Muslim Women in Glasgow, Scotland. Gender, Place \& Culture, 18(6), 716-731. http://doi.org/10.1080/0966369X.2011.617907

Sobur, A. (2004). Semiotika Komunikasi. Bandung.

Sugiyono. (2008). Metode Penelitian Kuantitatif Kualitatif dan R\&D. Bandung.

Susanthi, N. L. dan N. W. S. (2013). Komodifikasi Code-Mixing Bahasa Inggris Dalam Lirik Lagu Pop Bali: Studi Kasus Lirik Lagu Kis Band, (November).

Talani, N. S. S. dan W. O. J. (2015). Transformasi Diri Wanita Berhijab (Studi Fenomenologis Pada Afiliasi Organisasi Keislaman Di Kota Gorontalo, 1-18.

Triantini, Z. E. dan M. T. (2014). Menakar Kontekstualisasi Konsep Jilbab Dalam Islam. Qawwam, 8, 1-12.

Triyono, A. (2012). Produksi teks dalam perspektif ekonomi politik media. J, I(1), 18-29.

Retrieved

from https://publikasiilmiah.ums.ac.id/bitstream/handle/11617/1828/2_Agus

Triyono.pdf? sequence $=1$

Vera, N. (2014). Semiotika dalam Riset Komunikasi. Bogor.

Wahidah, F. (2015). Komodifikasi Nilai Agama Dalam Iklan Televisi (Studi Analisis Semiotik pada Iklan Wardah). Retrieved from http://eprints.walisongo.ac.id/4778/

Wibowo, I. S. W. (2013). Semiotika Komunikasi-Aplikasi Praktis Bagi Penelitian dan Skripsi Komunikasi. Jakarta. 